\title{
1. Neoliberal relations of poverty and the welfare state
}

\section{Sanford F. Schram}

In the United States, poverty has long been an intensely researched topic for welfare state analysts. Yet it has most often been studied in individualistic terms, focused on detailing the characteristics of those living in poverty, including most especially estimating their population size and composition. One unfortunate consequence of this individualizing is the tendency to see poverty as a result of the individual's background, personality, psychology, behavior and so on, thereby neglecting the social structural factors that lead to people being mired in poverty.

Recent attempts have sought to change that by conceiving of poverty in relational terms, including most significantly the relationship of the poor to those who are more fortunate and in a position to affect their life chances. Among these persons in relation with the poor are state actors who are assigned responsibility to monitor, manage, surveil and discipline welfare recipients to be market-compliant actors. These relations of poverty are in need of closer examination most especially as the welfare state, not just in the US, but in the developed world more generally, comes under pressure in an age of neoliberalism to integrate recipients into the market economy thereby overcoming their social exclusion while simultaneously reducing the state's burden for sustaining them. In fact, comparative analysis across countries of these shifts in relations between the poor and their state managers points to the variegated ways nations are enacting neoliberal welfare policy reforms. Based on such comparative analysis, this chapter highlights moves toward progressive responses even as neoliberal pressures for market compliance remain ascendant. 


\section{NEOLIBERAL RELATIONS OF POVERTY}

For too long, researchers, especially in the US, have almost always tended to focus on the individuals who are poor, what characteristics they have, and what is it about them as individuals that makes them poor, be it their personality, their values, their behavior, their racial or ethnic background (see Schram 1995). Class relations, the structure of power in society and other social structural and institutional constraints are far too often pushed in the background in the quest to study individuals in an empirical and ideally quantitatively measurable way. Researchers inevitably lose sight of the forest of broader contextual factors in order to focus on the trees of economically disadvantaged individuals. Yet, in recent years, a growing number of analysts have begun to counteract this pull to positivism by emphasizing in particular a 'relational' approach to the study of this topic (Emirbayer 1997; Desmond and Emirbayer 2009; Desmond 2016; Elwood et al. 2017; Lawson and Elwood 2018).

A relational understanding of social phenomena has a longstanding place in modern social science literature reaching back at least to Chester Barnard in his The Functions of the Executive (1938) where he distinctively emphasized the cooperative and interpersonal foundations of organizations. Barnard's influence ranged widely over the subsequent years coming to include radical scholars of social movements like Frances Fox Piven and Richard Cloward (1977) in their theory of the power of "poor people's movements' stemming from the disruptive ability that comes with their withholding consent and compliance in relationship to the powerful who dominate them. Social formations like poverty or impoverishment or even being poor, as in a poor individual, build off and emerge out of dependent relationships, be those relationships psychological, social, political or economic.

There are a variety of sources in actuality for the relational approaches that increasingly became popular in the social sciences in recent years (Fuhse 2014). Some drew from the work of Norbert Elias (1939), who rejected the overly deterministic character of structuralism and the overly agentistic orientation of individualism. Elias influenced social theorists like Charles Tilly (2001) to look for a more dynamic modeling of how social structures and individual choice-making interacted at psychological as well as sociological levels (Diani 2004). This sort of relational thinking resonated with the thinking of influential theorists like Anthony Giddens (1986) in his theory of structuration and Pierre Bourdieu (1977) in his conceptualization of what he called 'habitus'. The relational approach has been prominent among Scandinavian scholars of the Nordic 
welfare state (Harrikari and Rauhala 2016). It is increasingly influential in Europe more generally (Donati 2014).

By a relational approach, therefore, I mean nothing more than to focus on this fundamental social fact. Social conditions in particular should not be studied strictly in terms of the individual. Instead, an individual's poverty or economic hardship should be understood not in terms of a person's personal characteristics, behavior and practices in and of themselves, independent of the underlying social relationships. Instead, a better understanding is achieved when we place that person in a broader socioeconomic context that enables us to understand how relationships with others in a structured institutional setting affect what the individual can and cannot get to do that ends up producing that poverty or hardship.

A distinctive feature of relational approaches is how they change the way we conduct research. Matthew Desmond (2014) states:

Relational ethnography gives ontological primacy, not to groups or places, but to configurations of relations. The point of fieldwork becomes to describe a system of relations, "to show how things hang together in a web of mutual influence or support or interdependence or what have you, to describe the connections between the specifics the ethnographer knows by virtue of being there' (Becker 1996, p. 56). The relational ethnographer designs '[s]trategies of quite literally following connections, associations, and putative relationships' (Marcus 1998, p. 81), its proper object being 'chains of interdependence' (Weber 2001, p. 484; see also Beaud and Weber, 2003). Relational ethnography is not propelled by the logic of comparison, as is the multi-sited ethnography of sociology. It does not seek to understand if a certain group or community is peculiar vis-à-vis their counterparts in other contexts. It often does not seek to understand if a certain group or community is anything at all. Rather, it is 'designed around chains, paths, threads, conjunctions [that come to support] the argument of the ethnography' (Marcus 1998, p. 90). Most basically, a relational approach incorporates fully into the ethnographic sample at least two types of actors or agencies occupying different positions within the social space and bound together in a relationship of mutual dependence or struggle. (Desmond 2014, p. 554)

A relational approach to the study of poverty has the great virtue of placing an individual's condition, behavior and even beliefs in a broader context so as to better make sense of why people do what they do and believe what they believe. It helps us understand why it might be rational for poor people to make the 'bad' choices they make (Mullainathan and Shafir 2013). We can better understand how these allegedly bad choices are not really so much a product of some characteristics or propensity among poor people as individuals, but more the result of their context and the relationships that serve to create and reinforce that context. My 
specific focus is on how we have moved over the last four decades, at least since the Reagan presidency, to a neoliberal set of relations that shape and structure poverty and inequality in the US.

A key feature of the general orientation of neoliberalism is responsibilization (Hacker 2006) or the idea that we need to insist and enforce personal responsibility as much as possible in an age where elites manufacture austerity, starve the beast of government, hollow out the welfare state, insist on personal responsibility and then blame and punish the poor when they fail or are unable to effectively comply (Schram 2015). The neoliberal relations of poverty are highly disciplinary. They end up blaming people as individuals for the relationships that put them in adverse circumstances and force them often to make bad decisions for their choices are so limited. It makes people seem like they do not want to do better, to plan for their future, and so on, when in fact they simply cannot afford to.

With responsibilization, the neoliberal relations of poverty are masked and erased from consideration. We are encouraged to blame the poor for the poverty society imposes on them. Neoliberal relations of poverty operate by stealth. Under neoliberalism, it becomes all the more important to highlight and make these relationships explicit so that we do not allow the atrophying of consciousness to rationalize poverty today in hyper individualistic terms that only serve to reinscribe neoliberalism's insistence on personal responsibility as a rationalization for hollowing out the welfare state. Yet, in order to better understand these dynamics of the neoliberal relations of poverty, we need to first define neoliberalism, which I turn to in the next section.

\section{NEOLIBERALISM DEFINED}

In recent years, the effects of neoliberalism have cut to the bone (Stiglitz 2012). The Great Recession of 2008-09 was the worst economic downturn since the Great Depression of the 1930s. By the time its most devastating effects began receding in late 2012, and the economy's improvement became noticeable in 2013, many people were beginning to exhale a sigh of relief that things might return to normal after an extended period of massive hardship for individuals and families throughout the US. Yet it seemed that a new normal was emerging where economic opportunity for most people was not quite what it once was. In this transformed economy, the wealthy become ever wealthier, while the middle class shrinks and people with lower incomes - the working class and poor - are being disciplined to be market-compliant actors in an 
economy that left them with dwindling opportunities for achieving a decent standard of living.

As if these negative trends were not enough, mainstream political discourse diverted attention away from growing economic inequality and precarity and instead focused on the alleged dangers of high levels of public debt. The resultant manufactured austerity did nothing but accelerate the trend whereby growing numbers of people who suffered diminished economic prospects were made all the more subject to disciplinary practices of the state that punished them for their failure to succeed in a transformed economy. These changes take place during a time of neoliberalism. Neoliberalism is these days ascendant, continuing its rise since the years of the Reagan presidency. Neoliberalism is where there is increased emphasis on people practicing personal responsibility by applying economic logic to all forms of decision-making across a variety of spheres of life (Schram 2015). Neoliberalism disseminates economic rationality to be the touchstone not just for the market but for civil society and the state as well. Most dramatically it has led to wholesale revision in public policy in a number of domains to be more consistent with market logic in the name of better promoting market-compliant behavior by as much of the citizenry as possible. People are expected to practice personal responsibility by investing in their own human capital to make themselves less of a burden on society as a whole or face the consequences of the heightened disciplinary regime (Soss et al. 2011). As a result, post-Great Recession, the return of ordinary capitalism provided a new neoliberal normal of growing inequality and dwindling economic opportunities for most Americans. Under neoliberalism, the state buttresses markets rather than counters them and inequality grows virtually unabated, as not a bug but rather as a feature of this latest iteration of the return to ordinary capitalism. The shift to a new normal of a neoliberalized economy was by no means spontaneous. Joseph Stiglitz has written that these trends post-Great Recession are actually reflective of a long wave of state-induced economic transformation:

For thirty years after World War II, America grew together - with growth in income in every segment, but with those at the bottom growing faster than those at the top. The country's fight for survival brought a new sense of unity, and that led to policies, like the GI Bill, that helped bring the country even closer together. But for the past thirty years, we've become increasingly a nation divided; not only has the top been growing the fastest, but the bottom has actually been declining. The last time inequality approached the alarming level we see today was in the years before the Great Depression. If we are to reverse these trends in inequality, we will have to reverse some of the policies that have helped make America the most economically divided developed 
country and, beyond that, to take further actions to lessen the inequalities that arise on their own from market forces. (2012, pp. 4-5)

The new normal therefore was a long time in the making and public policy helped make it happen. The effects of the Great Recession have been serious indeed, but they are symptomatic of a larger economic restructuring where social welfare policies most significantly are revised to work consistently with the logic of the market rather than to counter it. This economic restructuring has not happened overnight, but instead, has come incrementally with economic downturns successively presenting opportunities to offload workers, outsource jobs and rebuild firms so that they can more efficiently and profitably, if also more heartlessly, participate in the neoliberalization of the global economy. As a result, people on the bottom of the socioeconomic ladder have increasingly been forced to try to survive on dwindling opportunities the transformed economy offers them or come under the purview of an increasingly disciplinary state.

While the new normal represented a break with the past, it also reflected continuity especially for selected marginalized populations, low-income African Americans in particular. In fact, the return of ordinary capitalism post the Great Recession has intensified preexisting long-term negative trends in income, housing, health care, social welfare and criminal justice, as well as overall well-being for many African Americans. A case could be made that these persistent racial disparities were not simply the result of failed public policies but that race itself was a critical constitutive ingredient in the ongoing rollout of a neoliberal paternalistic regime of poverty governance. Race facilitated the institution of policies designed to contain low-income populations and manage their poverty problems so that they did not become a burden for the rest of society. Further, those policies (from welfare-to-work to mass incarceration) help reinscribe race as a marker of who is innocent and who is guilty, who is deserving and who is not. In other words, persistent racial disparities in quality-of-life indicators were not a failure of the neoliberal paternalistic regime of poverty management but were instead its very raison d'être, reflective of a systematic effort to exploit racial divisions as a way of justifying advanced marginality among low-income African Americans (and other people of color).

Thomas Piketty (2014) has suggested that the 1945-73 period that Stiglitz references (i.e., what is often called the 'Great Compression'), when wages rose with economic growth and there was a reduction in inequality, was actually an anomaly in the history of capitalism. While African Americans and other racial and ethnic minorities did not benefit as much as whites during this period, for the bulk of Americans this was 
a distinctive time where, to turn a phrase, a rising tide was lifting most boats, if not all.

Yet on the basis of examining several hundred years of data across several countries, Piketty concludes that the normal course of affairs for ordinary capitalism is where the returns from capital exceed economic growth so as to concentrate wealth at the top and increase inequality. In other words, most often a rising tide lifts the boats of the well-off but not really anyone else. From this perspective, we have indeed, post the Great Recession, returned to the normal course of affairs for ordinary capitalism, where the economy grows, but so as to increase the concentration of wealth at the top. The aftermath of the Great Recession has included an acceleration of that trend since the mid-1970s with the economy growing to create more inequality by concentrating wealth at the uppermost top of the income distribution, to the point of producing a new Gilded Age of 'patrimonial capitalism' where the returns from capital help ensure that inherited wealth is the main driver of this extreme inequality. Piketty calls for a global wealth tax as the only solution to the inevitability of increasing concentration of wealth at the top. This is surely a utopian gesture, as Piketty himself recognizes, for there is not even a governmental body in existence to collect this tax.

Piketty's analysis therefore has an air of inevitability, that obdurate impersonal economic forces will be sustaining the new normal long into the future. Yet as ordinary people of all backgrounds persist in struggling to come to grips with this new normal, we must ask whether it is inevitable that economic forces will continue to generate greater levels of inequality and whether the ordinary people are in fact powerless to respond politically.

In this sense neoliberalism is not just another phase of liberal capitalism, though it is that it is still more than seamlessly the product of the market economy's evolution. It is not so economically determined and fated to be by market operations that inevitably concentrate wealth at a faster rate than overall growth as Piketty sometimes seems to suggest. Instead, the growing inequality of the neoliberal era is in large part the product of public policy. The period of the Great Compression was a time of what we call Keynesianism, named for the great economist John Maynard Keynes who promoted the idea that the state should serve as a counter to the market. Keynesianism enacted what Karl Polanyi called the 'double movement', where the state operated independently of the market to counter its ill effects and promote economic stability that could work for the benefit of ordinary people. The Great Compression was in no small part a result of the success of Keynesian policies. Yet, as Keynesianism began to fail in the 1980s, probably due to globalization 
that made it more difficult for the national government to counter a globalizing economy, people began to lose faith in the ability of government to implement Keynesian counter-cyclical policy effectively. This created an opening for conservatives to push for moving away from Keynesian policies that involved the heavy hand of the state.

Yet, given the deep path dependencies that came with people being accustomed to the state being there to regulate the economy and offer social protection from the vagaries of the market, rolling back big government was reduced largely to Reaganesque rhetoric, popular though it was even among Democrats like Bill Clinton. So, in response, critics of Keynesianism had to move to Plan B: if you could not get rid of the welfare state, the next best thing was to neoliberalize it. Rather than go back to classical Adam Smithian laissez-faire market fundamentalism, instead marketize the state. Keynesianism made a sharp division between the market and the state; it had the state serve as an alternative to the market offering social protection, and an independent state regulated the market. Under neoliberalism, the state did not go away but instead it was marketized: erase the sharp distinction between the market and the state, blur the boundary between the market and the state to bring in market actors to run state operations along market lines consistent with market logic in order to better buttress rather than counter the market. Neoliberalism in this sense most critically is not so much about the market as it is about the state; it is about the marketization of the state in order to better support rather than counter markets. With these marching orders, state actors have over the last few decades insistently and persistently neoliberalized the state. With the neoliberalization of the state, the neoliberal relations of poverty get instigated via state policy. We see this no better when we look at social welfare policies.

\section{NEOLIBERAL WELFARE}

The Keynesian welfare state that arose during the Great Compression provided social protection for those who were seen as deserving of public assistance given their inability to provide for themselves and their family due to unemployment, disability, retirement, death of a wage-earning spouse and other conditions (Schram 2015). The welfare state was an alternative to the market. The welfare state still exists but under neoliberalism it is increasingly focused on disciplining recipients to be market compliant, by minimizing their time receiving public assistance and enhancing their motivation and ability to fit into the market's job structure. The welfare state buttresses rather than counters the market. It 
does this by reorganizing its own operations to run along market lines according to market logic (Soss et al. 2011). Social welfare programs are often run by for-profit providers, who face market competition (often simulated through performance-management accountability schemes), and who are incentivized to run their programs as cheaply as possible to make a profit by moving recipients as quickly as possible off assistance and into the job market. Under these conditions, it is not surprising that providers have an entirely different orientation, where once recipients were the clients, now employers are the clients. This revised orientation underscores how neoliberalizing welfare programs, whether they are unemployment assistance, disability or public assistance for the poor, are now more about buttressing the market rather than countering it.

Neoliberalism is most often seen as being about promoting market freedom and it is undoubtedly about enhancing the power of the market and the supremacy of market logic (Brown 2015). Yet, the ongoing neoliberalization of the welfare state demonstrates that neoliberalism is critically about the state, even if it is the marketization of the state. Further, neoliberalism is most seen as emphasizing the freedom in market freedom, as in deregulation and reduced reliance on a hollowed out welfare state. Yet, in-depth examination of the neoliberalization of welfare demonstrates that neoliberalism is also about disciplining people to be market compliant. The key to understanding this seeming contradiction is emphasizing the critical role in neoliberalism played by the term 'responsibilization'. Responsibilization implies a process rather than a condition. It is something that gets done rather than a preexisting condition. With a shift to a neoliberal orientation, people are expected to be personally responsible by achieving their well-being via the market and relying on market logic as much as possible to make the economically right choices in all areas of their lives. In this way, they should be able to eliminate their need to rely on the state. Yet, when people fail to be able to be responsible on their own, the neoliberalized welfare state is increasingly expected to step in to discipline recipients to be market compliant. The social control dimensions of welfare that have historically always been there now are accentuated (Piven and Cloward 1971).

If we survey the changes occurring across welfare states in the developed world (Schram 2006), we can see that what Gøsta EspingAndersen (1990) calls the 'Three Worlds of Welfare Capitalism' persists under neoliberalism. The Nordic Social-Democratic welfare states of the Scandinavian countries have followed the Conservative, ChristianDemocratic strong-state welfare states of countries like France and Germany and the Liberal Democratic welfare states of the Anglo countries in responding to neoliberalizing pressures in a globalizing 
economy. Yet, when they have done so they have tended to persist in maintaining their differences. The neoliberalizing pressures are real but the differences across countries and cultures condition and constrain the extent to which neoliberalization results in a hollowing out of the welfare state. The take away of this research is that neoliberalization is not fated to be as some inexorable force of economic determinism but instead is in no small part a political choice manifested in the crafting of public policy (Schram 2015).

\section{IN AN AGE OF RIGHT-WING REACTION}

Today, there is a rising tide of right-wing reaction that poses a serious threat to the viability of the welfare state in liberal democracies in the developed world. Growing anxieties associated with perceived threats from the forces of globalization have led to an upsurge of right-wing populist reaction in country after country, in Europe, the US and elsewhere. Concerns about demographic diversification, multiculturalism and immigration have led to a rise in white nationalism. The welfare state is implicated in these developments. Far-right leaders like Viktor Orban in Hungary have actively moved to promote what they call 'illiberal democracy', where the rule of law is compromised in the name of consolidating power to impose dramatic changes that include undercutting individual rights (Bershidsky 2018). Minorities in particular are made more vulnerable and the state is freed to stand up for the white indigenous population against immigrants. As is typical of right-wing populism, Orban's platform includes a defense of the welfare state but only on behalf of the dominant nationality.

Denmark is an interesting case in point. Denmark has proven to be a resilient social democracy with a robust welfare state that has produced a highly contented population. Nonetheless, in recent years, reactionary forces challenging the growth in the number of Muslim immigrants has led to the government periodically responding to demands to limit welfare state benefits to immigrants. The Danish People's Party has transformed itself from a critic of the welfare state to its defender but this time as a defender that promises to defend the welfare state by limiting immigrants' access to benefits. This approach has actually led to coalition-building with the Social Democrats (Milne 2017).

Other Scandinavian countries face similar threats to their commitments to liberal democracy and minority rights. In Sweden, the issue of immigration has become quite volatile where the far-right antiimmigrant Democrat Party is rising. Should they come to power, a 
referendum like the Brexit vote in the United Kingdom could result (Milne 2018). The European Union is increasingly seen as the enemy imposing external pressure on these countries to accept diversification that they have long resisted. These are startling developments for countries that have prized their commitments to liberal democracy, social solidarity and inclusiveness.

These developments occur in the context of ongoing neoliberalization. Nordic welfare states have survived but have accommodated neoliberalizing trends to move the welfare policy in a more market-centered direction. Neoliberal and right-wing populist elements can combine to produce a version of a corporatist-authoritarian state (Schram and Pavlovskaya 2017). In the neoliberal corporatist-authoritarian state, business elites collude with right-wing populists to rule by imposing a draconian state regime while freeing business to engage in consolidation of the corporate sector. The neoliberal corporatist-authoritarian cabal has its variations across the western world today.

A good example is the presidency of Donald J. Trump in the US, where right-wing populist rhetoric against immigrants and other minorities diverts attention from a corporate dominated cabinet. At times, there are promises that neoliberal market-oriented policies such as the emphasis on for-profit colleges and charter schools will benefit ordinary people, though the results rarely if ever live up to the hype and often turn out to be the opposite. For-profit prisons for people seeking asylum at the border is but the most draconian example.

The neoliberal relations of poverty are fraught with cruelty today as the Trump approach to disciplining marginalized populations, immigrants in particular, becomes all too apparent. Understanding the structural bases for such relations is essential if we are to move past the worst versions of neoliberalism in the age of right-wing populism.

\section{CONCLUSION}

The current neoliberalizing of the welfare state is a political choice that accentuates focus on the poor as deficient citizen-subjects who need to be disciplined for their failure to be market compliant. Neoliberalism's focus on responsibilizing the poor erases what I am calling the neoliberal relations of poverty, foregrounding the isolated individual as the cause of their own poverty. Neoliberalism accentuates 'blaming the poor' for their own poverty (Ryan 1976). The neoliberalized world can be, as we have seen, very Trumpian. It is also Randian, that is it is reminiscent of the emphasis in Ayn Rand's thinking that we are a society of winners and 
losers (Hacker and Pierson 2016). Trump emphasizes being a winner not a loser. He allegedly did not want his son named after him, telling his wife Ivana that it would look bad for him if Junior turned out to be a loser (Ioffe 2018). Trump, it seems, has always envisioned the world as zero-sum where winners win at the expense of losers (evidently even in thinking about his relationship to his children). Be a winner; not a loser. Losers lose because they are not good enough. They should be looked down upon and suffer the consequences for their personal failings. This neoliberal orientation represents a heightened perspective of competitive capitalism taken to a brutal, even cruel level. A Trumpian neoliberal perspective of a world of winners and losers is blind to the underlying neoliberal relations of poverty that significantly create the poverty that poor people must endure. As inequality skyrockets under neoliberalism, the welfare state increasingly is at risk of not being able to counteract the adverse effects for people on the bottom. Instead, a neoliberal process of responsibilization is put in place. Manufacture austerity, starve the beast, hollow out the welfare state, insist on market compliance via an ethic of personal responsibility, discipline recipients for failure to be market compliant, and blame the poor for their own poverty as a product of their own personal choices.

In the current era, resisting the process of neoliberalization of the welfare state has proven to be difficult. Even Nordic social democracies are vulnerable to these pressures in a globalizing world economy. Yet, they show that resistance is possible. There are ways to bend pressures for neoliberalization to sustain and even enhance forms of social protection. The cruel brutality of the Trumpian neoliberal orientation need not become the social ethic of our time.

\section{REFERENCES}

Barnard, C. (1938), The Functions of the Executive, Cambridge: Harvard University Press.

Beaud, S. and F. Weber (2003), Guide de l'enquête de terrain: produire et analyser des données ethnographiques, Paris: Éditions La Découverte.

Becker, H. (1996), 'The epistemology of qualitative research', in R. Jessor, A. Colby, and R. Shweder (eds), Ethnography and Human Development: Context and Meaning in Social Inquiry, Chicago, Illinois: University of Chicago Press, pp. 53-71.

Bershidsky, L. (2018), 'Europe must learn to work with its autocrats', Bloomberg Opinion, 9 April.

Bourdieu, P. (1977), Outline of a Theory of Practice, New York: Cambridge University Press. 
Brown, W. (2015), Undoing the Demos: Neoliberalism's Stealth Revolution, New York: Zone Books.

Desmond, M. (2014), 'Relational ethnography,' Theoretical Sociology 43 (5), 547-79.

Desmond, M. (2016), Evicted: Poverty and Profit in the American City, New York: Crown.

Desmond, M. and M. Emirbayer (2009), 'What is racial domination?', Du Bois Review: Social Science Research on Race 6 (2), 335-55.

Diani, M. (2004), 'Networks and participation', in D. Snow, D.S. Soule, and H. Kriesi (eds), The Blackwell Companion to Social Movements, Oxford: Blackwell, pp. 339-59.

Donati, P. (2014), 'Relational goods and their subjects: The ferment of a new civil society and civil democracy', Recerca, Revista de Pensament i Analisi 14, $19-46$.

Elias, N. (1939 [2000]), The Civilizing Process: Sociogenetic and Psychogenetic Investigations, London: Blackwell.

Elwood, S., V. Lawson, and E. Sheppard (2017), 'Relational geographical poverty studies', Progress in Human Geography 41 (6), 745-65.

Emirbayer, M. (1997), 'Manifesto for a relational sociology', American Journal of Sociology 103 (2), 281-317.

Esping-Andersen, G. (1990), Three Worlds of Welfare Capitalism, Cambridge, UK: Polity Press.

Fuhse, J. (2014), 'Theorizing social networks: Relational sociology of and around Harrison White', International Review of Sociology 25 (1), 15-44.

Giddens, A. (1986), The Constitution of Society: Outline of the Theory of Structuration, Berkeley: University of California Press.

Hacker, J. (2006), The Great Risk Shift: The New Economic Insecurity and the Decline of the American Dream, New York: Oxford University Press.

Hacker, J. and P. Pierson (2016), American Amnesia: How the War on Government Led us to Forget what Made America Prosper, New York: Simon and Schuster.

Harrikari, T. and P.-L. Rauhala (2016), Social Change and Social Work: The Changing Societal Conditions of Social Work in Time and Place, London: Routledge.

Ioffe, J. (2018), 'The real story of Donald Trump, Jr', GQ, accessed 30 March 2019 at https://www.gq.com/story/real-story-of-donald-trump-jr.

Lawson, V. and S. Elwood (eds) (2018), Relational Poverty Politics: Forms, Struggles and Possibilities, Athens, Georgia: University of Georgia Press.

Marcus, G. (1998), Ethnography through Thick and Thin, Princeton: Princeton University Press.

Milne, R. (2017), 'Denmark's centre-left seeks common ground with populists: Social Democrats fear losing out to anti-immigrant party', Financial Times, 10 July.

Milne, R. (2018), 'Europopulism: Immigration provides opening for Sweden's right wing', Financial Times, 16 August.

Mullainathan, S. and E. Shafir (2013), Scarcity: Why Having Too Little Means So Much, New York: Time Books. 
Piketty, T. (2014), Capital in the 21st Century, Cambridge: Harvard University Press.

Piven, F. and R. Cloward (1971), Regulating the Poor: The Functions of Public Welfare, New York: Pantheon.

Piven, F. and R. Cloward (1977), Poor People's Movements: Why they Succeed, how they Fail, New York: Vintage.

Ryan, P. (1976), Blaming the Victim, Revised Edition, New York: Vintage.

Schram, S. (1995), Words of Welfare: The Social Science of Poverty and the Poverty of Social Science, Minneapolis: University of Minnesota Press.

Schram, S. (2006), Welfare Discipline: Discourse, Governance, and Globalization, Philadelphia: Temple University Press.

Schram, S. (2015), The Return of Ordinary Capitalism: Neoliberalism, Precarity, Occupy, New York: Oxford University Press.

Schram, S. and M. Pavlovskaya (2017), 'Introduction', in S. Schram and M. Pavlovskaya (eds), Rethinking Neoliberalism: Resisting the Disciplinary Regime, New York: Routledge, pp. xiii-xxvii.

Soss, J., R. Fording, and S. Schram (2011), Disciplining the Poor: Neoliberalism and the Persistent Power of Race, Chicago: University of Chicago Press.

Stiglitz, J. (2012), The Price of Inequality, New York: Norton.

Tilly, C. (2001), 'Relational origins of inequality', Anthropological Theory 1 (3), 355-72.

Weber, F. (2001), 'Settings, interactions and things: A plea for multi-integrative ethnography', Ethnography 2 (4), 475-99. 